\title{
FAKTOR-FAKTOR YANG BERHUBUNGAN DENGAN KEJADIAN PLEBITIS PADA PASIEN YANG TERPASANG INFUS DI RUMAH SAKIT IMELDA PEKERJA INDONESIA (RSU IPI) MEDAN
}

\author{
Meriani Herlina, Anggi Gandha Prasthyo Jafa \\ Dosen Prodi S1Keperawatan, STIKes Imelda, Jalan Bilal Nomor 52 Medan; \\ Alumni STIKes Imelda \\ E-mail: siahaanmeriani@yahoo.co.id
}

\begin{abstract}
ABSTRAK
Infeksi nosokomial merupakan infeksi yang terjadi pada pasien ketika berada di rumah sakit atau ketika berada di fasilitas kesehatan lainnya. Phlebitis adalah infeksi nosokomial yang berasal dari mikroorganisme yang dialami pasien yang diperoleh selama pasien di rawat di rumah sakit yang diikuti dengan manifestasi klinis yang sekurang-kurangnya $3 \times 24$ jam. Penelitian ini bertujuan untuk menganalisa adanya hubungan antara faktor-faktor penyebab phlebitis dengan kejadian phlebitis. Penelitian dilakukan pada Juli tahun 2018 dengan pendekatan cross sectional. Populasi dalam penelitian ini adalah seluruh pasien yang terpasang infus selama bulan Juli tahun 2018 di ruangan ICU, Tulip, Asoka dan Mawar. Populasi pada penelitian ini adalah 269 orang. Tehnik sampling pada penelitian ini adalah proportionate stratified random sampling dengan demikian jumlah sampel adalah 160 orang. Analisis statistik yang digunakan uji chi square. Hasil analisis bivariat menunjukkan bahwa nilai $p=0,000$ ada hubungan ukuran infus dengan plebitis, nilai $p$ value 0,000 ada hubungan jenis cairan dengan plebitis, nilai p 0,001 ada hubungan lokasi pemasangan dengan plebitis, nilai $p$ value 0,000 ada hubungan lama infus terpasang dengan plebitis, nilai $p$ value 0,000 ada hubungan jumlah insersi dengan plebitis. Disarankan bagi responden Disarankan kepada responden agar tetap meningkatkan kinerja secara profesional untuk mencegah terjadinya plebitis
\end{abstract}

Kata kunci : infeksi nosokomial, plebitis

\section{PENDAHULUAN}

Rumah sakit merupakan unit pelayanan medis yang sangat kompleks. Kompleksitasnya tidak hanya dari segi jenis dan macam penyakit yang harus memperoleh perhatian dari para dokter (medical provider) untuk menegakkan diagnosis dan menentukan terapinya (upaya kuratif), namun juga adanya berbagai macam peralatan medis dari yang sederhana hingga yang modern dan canggih. Hal lain yang merupakan kompleksitas sebuah rumah sakit adalah adanya sejumlah orang/pers onel yang secara bersamaan berada di rumah sakit, sehingga rumah sakit menjadi sebuah gedung pertemuan sejumlah orang/pers onel secara serempak, berinteraksi langsung ataupun tidak langsung mempunyai kepentinga $\mathrm{n}$ dengan penderita-penderita yang dirawat di rumah sakit (Darmadi, 2008).

Infeksi nosokomial dapat terjadi pada penderita, tenaga kesehatan, dan juga setiap orang yang datang ke rumah sakit. Infeksi yang ada di pusat pelayanan kesehatan ini dapat ditularkan atau diperoleh melalui petugas kesehatan, orang sakit, pengunjung yang berstatus karier atau karena kondisi rumah sakit (Septiari, 2012).

Infeksi nosokomial menyebabkan 1,4 juta kematian setiap hari di seluruh dunia. Presentasi infeksi nosokomial di rumah sakit dunia mencapai 9\% (variasi $3-2 \%$ ) atau lebih 1,4 juta pasien rawat inap di rumah sakit seluruh dunia mendapatkan infeksi nosokomial. Suatu penelitian yang dilakukan WHO menunjukkan bahwa sekitar $8,7 \%$ dari 55 rumah sakit dari 14 negara yang berasal dari Eropa, Timur Tengah, Asia Tenggara, dan Pasifik menunjukkan adanya infeksi nosokomia 1 dan untuk Asia Tenggara sebanyak 10,0\% (WHO, 2012).

Salah satu infeksi nosokomial adalah infeksi luka infus atau phlebitis. Phlebitis merupakan daerah bengkak, kemerahan, panas, 
dan nyeri pada kulit sekitar tempat kateter intravaskular dipasang (kulit bagian luar). Jika phlebitis disertai dengan tanda-tanda infeksi lain seperti demam dan pus (keluarnya nanah) yang keluar dari tempat tusukan, ini digolongkan sebagai infeksi klinis bagian luar. Selain pasien mendapatkan infeksi dari layanan kesehatan yang diberikan, prosedur invasiv juga beresiko bagi tenaga kesehatan. Tenaga kesehatan dapat mengalami cedera tertusuk jarum atau kontaminasi pada membran mukosa atau kulit yang tidak utuh ketika melakukan prosedur tersebut (Depkes, 2013).

Diketahui bahwa tingkat keparahan gejala phlebitis ditentukan berdasarkan skala derajat phlebitis (Visual Infusion Phlebitis Score) mulai dari skala 0 sampai dengan 5 berdasarkan rekomendasi The Infusion Nurses Nociety (Wayunah, 2011). Faktor penyebab dari phlebitis terdiri dari internal adalahusia, status gizi, stres, kondisi vena, faktor penyakit pasien rawat inap yang terpasang infus serta jenis kelamin (Perry dan Potter, 2009).Sedangkan faktor eksternal dari phlebitis terdiri dari 3 jenis yaitu:faktor kimia, factor mekanik dan faktorbakterial (Alexander, et al, 2011).

Salah satu yang memberi kontribusi terhadap faktor bakterial dari phlebitis adalah durasi pemasangan infus yang terlalu lama. Salah satu cara untuk mengatasinya adalah dengan merotasi lokasi infus apabila ada kontraindikasi. Pada penelitian yang dilakukan oleh Christian Komaling, dkk (2014) diketahui bahwa dari total 21 responden yang lama pemasangan infus lebih dari 72 jam ( $\geq 3$ hari), 16 responden $(27,6 \%)$ mengalami phlebitis, sedangkan 5 responden $(8,6 \%)$ tidak mengalam i phlebitis. Sedangkan dari 37 responden yang dipasangi infus 48-72 jam ( $\leq 3$ hari), 4 responden $(6,9 \%)$ mengalami phlebitis, sedangkan 33 responden $(56,9 \%)$ tidak mengalami phlebitis (Komaling, 2014).

The Center for Disease Control and Prevention telah menyusun penggantian infus tidak boleh lebih dari 72 jam, kecuali untuk penanganan darah dan lipid emulsi diganti tiap 24 jam. Hal ini disebabkan oleh bakteri yang masuk melalui cairaninfus atau peralatan yang terkontaminasi menggandakan diri sepanjang waktu, penggantian set infus secara teratur mengurangi kemungkinan kontaminasi. Semakin lama infus dipasang di satu area, maka akan semakin besar kemungkinan terjadinya infeksi. Kejadian infeksi di rumah sakit rentan terjadi pada pasien yang berusia tua, karena beratnya penyakit yang diderita, dan daya imunitasnya berkurang (Nihi, 2010).

Peran perawat dalam hal ini adalah mencegah terjadinya plebitis dengan cara menetukan lokasi pemasangan vena dengan tepat, melakukan perawatan infus dengan cara mengganti infus tidak lebih dari 72 jam, melakukan inserasi dengan tepat dan dapat memilih ukuran abocat sesuai ukuran vena atau usia pasien. Berdasarkan latar belakang diatas peneliti merasa tertarik untuk meneliti faktorfaktor yang berhubungan dengan kejadian plebitis pada pasien yang terpasang infus di rumah sakit Imelda Pekerja Indonesia.

\section{METODE}

Desain penelitian yang digunakan adalah $\mathrm{d}$ eskriptif corelasi dengan pendekatan crossectio nal yang bertujuan untuk mengetahui faktorfaktor apakah yang berhubungan dengan kejadian phlebitis pada pasien yang terpasang infus di RS IPI.

\section{Lokasi dan Waktu Penelitian}

Penelitian ini dilakukan di ruang rawat inap yaitu ICU, Tulip, Asoka dan Mawar Rumah Sakit Imelda Medan dimulai pada bulan Juli tahun 2018.

\section{Populasi dan Sampel}

Populasi dalam penelitian ini adalah seluruh pasien yang terpasang infus selama bulan Juni tahun 2018 di ruangan ICU, Tulip, Asoka dan Mawar. Populasi pada penelitian ini adalah 269 orang. Besarnya sampel dalam penelitian ini ditemukan dengan cara rumus slovin yaitu sebanyak160 orang. Tehnik sampling pada penelitian ini adalah proportiona te stratified random sampling yaitu sebanyak 38 orang. 


\section{Defenisi Operasional}

Tabel 1. Definisi Operasional Penelitian

\begin{tabular}{lllll}
\hline No & $\begin{array}{l}\text { Variabel } \\
\text { independen }\end{array}$ & Defenisi Operasional & Cara Penggukuran & Skala Ukur \\
\hline 1 & Plebitis & $\begin{array}{l}\text { Daerah bengkak, kemerahan, } \\
\text { panas, dan nyeri pada kulit sekitar } \\
\end{array}$ & $\begin{array}{l}\text { Diukur dengan melihat } \\
\text { tempat terpasangnya kateter infus atau tidak flebitis. }\end{array}$ & Nominal \\
& & $\begin{array}{l}\text { Terjadi plebitis diberi } \\
\text { nilai 1 } \\
\text { Tidak ada diberi nilai 0 }\end{array}$ & \\
& & & &
\end{tabular}

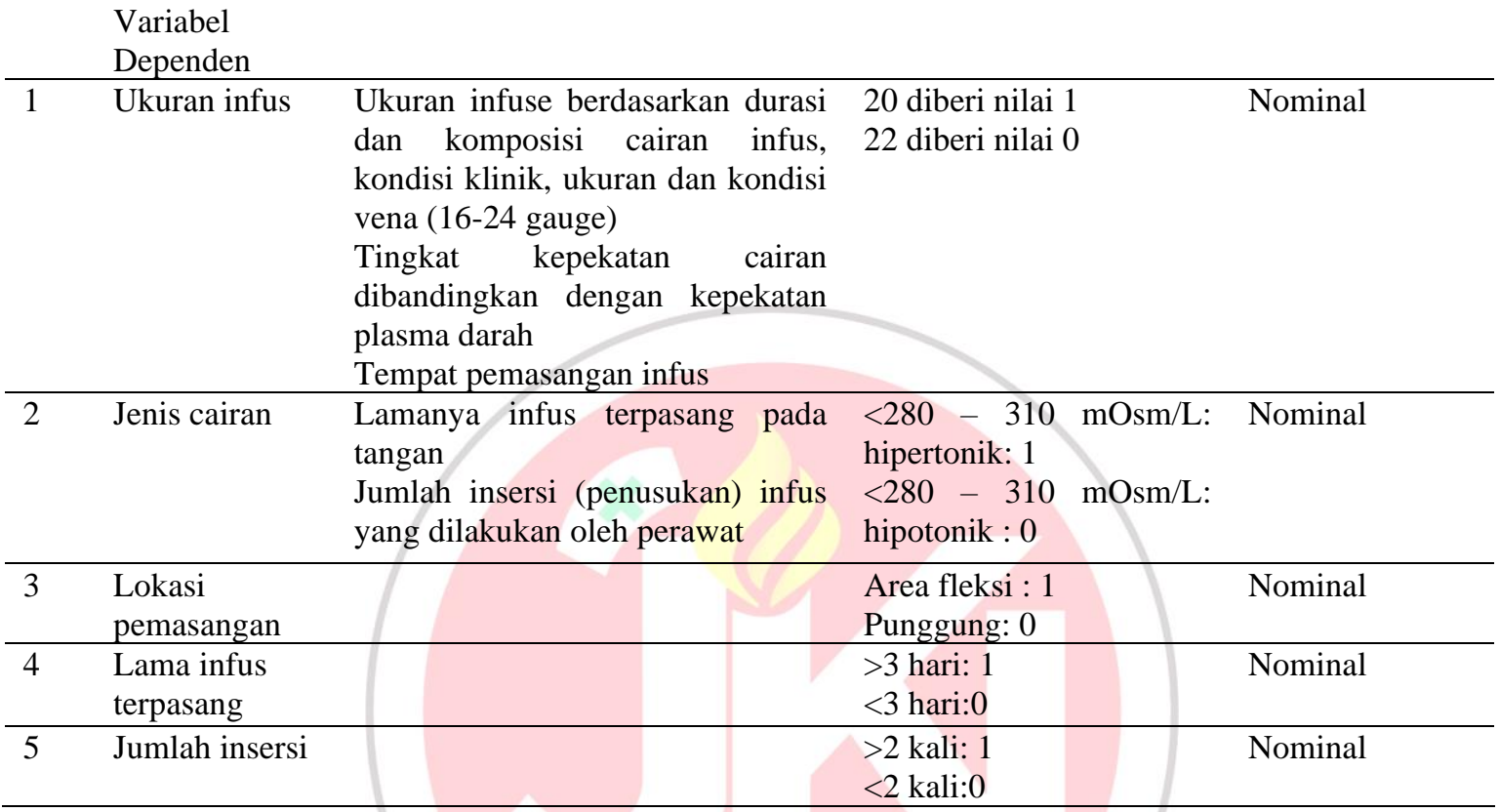

\section{Analisa Data}

1. Analisa Univariat digunakan untuk mendekripsikan data yang dilakukan pada tiap variable dari hasil penelitian. Data disajikan dalam table distribusi frekuensi.

2. Analisa Brivariat untuk mengetahui hubungan (korelasi) antara variable bebas (independen variabel) dengan variable terikat (depende variabel). Untuk membukt ikan adanya hubungan yang signifikan antara variable terikat digunakan analisis Chi-square, pada batas kemaknaan perhiungan statistic $\mathrm{P}$ value $(0,05)$. Apabila hasil perhitungan menunjukkan nilai $\mathrm{P}<\mathrm{P}$ value $(0,05)$ maka dikatakan $(\mathrm{Ho})$ ditolak dan (Ha) diterima, artinya kedua varaiabel secara statistic mempunyai hubungan yang signifikan.
HASIL

Tabel 2. Distribusi frekuensi responden berdasarkan umur, pendidikan, jenis kelamin dan lama kerja

\begin{tabular}{|c|c|c|c|}
\hline No & $\begin{array}{l}\text { Umur } \\
\text { (Tahun) }\end{array}$ & $\begin{array}{l}\text { Frekuensi } \\
\text { (jumlah) }\end{array}$ & $\begin{array}{l}\text { Persentasi } \\
(\%)\end{array}$ \\
\hline 1 & $20-30$ & 13 & 22,81 \\
\hline 2 & $31-40$ & 25 & 43,86 \\
\hline 3 & $41-50$ & 38 & 66,67 \\
\hline 4 & $51-60$ & 30 & 52,63 \\
\hline 5 & $61-70$ & 28 & 49,12 \\
\hline 6 & $71-80$ & 26 & 45,61 \\
\hline Total & & 160 & 100 \\
\hline No & Jenis Kelamin & $\begin{array}{l}\text { Frekuensi } \\
\text { (jumlah) }\end{array}$ & $\begin{array}{l}\text { Persentasi } \\
(\%)\end{array}$ \\
\hline 1 & Laki-laki & 53 & 29,82 \\
\hline 2 & Perempuan & 107 & 70,18 \\
\hline Total & & 160 & 100 \\
\hline
\end{tabular}

Berdasarkan tabel diatas, diketahui bahwa mayoritas responden berumur 41 - 50 tahun yaitu sebanyak 38 orang $(66,67 \%)$, sedangkan minoritas berumur $20-30$ tahun yaitu 
sebanyak 13 orang $(22,81 \%)$. Berdasarkan jenis kelamin, mayoritas responden berjenis kelamin perempuan yaitu sebanyak 107 orang $(70,18 \%)$, minoritas berjenis kelamin laki-laki yaitu sebanyak 53 orang $(29,82 \%)$.

Berdasarkan penelitian, kejadian plebitis di ruang rawat inap dapat dilihat pada tabel dibawah ini.

Tabel 3. Distribusi frekuensi responden berdasarkan kejadian plebitis

\begin{tabular}{llll}
\hline No & Kejadian & Frekuensi & Persentasi \\
\hline
\end{tabular}

\begin{tabular}{llll}
\hline & plebitis & (Jumlah) & $\mathbf{( \% )}$ \\
\hline 1 & Terjadi plebitis & 22 & 13,8 \\
\hline 2 & $\begin{array}{l}\text { Tidak terjadi } \\
\text { plebitis }\end{array}$ & 138 & 86,3 \\
\multicolumn{2}{l}{ Total } & 160 & 100 \\
\hline
\end{tabular}

Berdasarkan tabel diatas, diketahui bahwa mayoritas tidak terjadi plebitis yaitu sebanyak 138 orang $(86,3 \%)$, minoritas terjadi plebitis yaitu 22 orang $(24,60 \%)$.

Tabel 3. Distribusi frekuensi responden berdasarkan hubunganukuran infus yang digunakan dengan kejadian plebitis

\begin{tabular}{llllllll}
\hline No & $\begin{array}{l}\text { Kejadian } \\
\text { plebitis }\end{array}$ & \multicolumn{2}{l}{ Ukuran Infus } & \multicolumn{3}{l}{ Total } \\
\cline { 3 - 6 } & & \multicolumn{2}{l}{ Ukuran 22 } & \multicolumn{2}{l}{ Ukuran 20 } & & \\
\cline { 3 - 7 } & & f & \% & f & \% & f & \% \\
\hline 1 & $\begin{array}{l}\text { Tidak } \\
\text { terjadi }\end{array}$ & 100 & 62,5 & 38 & 23,75 & 138 & 86,25 \\
\hline 2 & terjadi & 2 & 1,25 & 20 & 12,50 & 22 & 13,75 \\
\hline Total & & 102 & 63,75 & 58 & 36,25 & 160 & 100 \\
\hline
\end{tabular}

Berdasarkan tabel diatas, diketahui bahwa minoritas terjadi plebitis yaitu 22 orang mayoritas tidak terjadi plebitis yaitu 138 orang $(86,25 \%)$ dengan ukuran infus yang digunakan adalah ukuran 22 yaitu 100 orang $(62,5 \%)$ dan $(13,75 \%)$ dengan ukuran 22 yaitu 2 orang $(1,25 \%)$ dan ukuran 20 yaitu 20 orang ukuran 20 yaitu 38 orang $(23,75 \%)$, sedangkan

Tabel 5. Distribusi frekuensi responden berdasarkan hubungan kejadian plebitis dengan jenis cairan yang digunakan

\begin{tabular}{|c|c|c|c|c|c|c|}
\hline \multirow[t]{3}{*}{ No } & \multirow{3}{*}{$\begin{array}{l}\text { Kejadian } \\
\text { plebitis }\end{array}$} & \multicolumn{3}{|c|}{ Jenis Cairan } & \multirow{2}{*}{\multicolumn{2}{|c|}{ Total }} \\
\hline & & \multicolumn{2}{|c|}{ Hipotonik } & Hipertonik & & \\
\hline & & $\mathbf{f}$ & $\%$ & F $\%$ & $\mathbf{f}$ & $\%$ \\
\hline 1 & $\begin{array}{l}\text { Tidak } \\
\text { terjadi } \\
\end{array}$ & 93 & 58,12 & $45 \quad 28,13$ & 138 & 86,25 \\
\hline 2 & terjadi & 1 & 0,63 & 13,12 & 22 & 13,75 \\
\hline Total & & 94 & 58,75 & 41,25 & 160 & 100 \\
\hline
\end{tabular}

Berdasarkan tabel diatas, diketahui bahwa mayoritas tidak terjadi plebitis yaitu 138 orang $(86,25 \%)$ dengan jenis cairan yang digunakan adalah hipotonik yaitu 93 orang $(58,12 \%)$ dan minoritas terjadi plebitis yaitu 22 orang $(13,75 \%)$ dengan jenis cairan hipotonik yaitu 1 orang $(0,63 \%)$ dan hipertonik yaitu 21 orang hipertonik yaitu 45 orang $(28,13 \%)$, sedangkan $(13,12 \%)$. 
Tabel 6. Distribusi frekuensi responden berdasarkan hubungan kejadian plebitis dengan lokasi pemasangan

\begin{tabular}{|c|c|c|c|c|c|c|c|}
\hline \multirow[t]{3}{*}{ No } & \multirow{3}{*}{$\begin{array}{l}\text { Kejad } \\
\text { ian } \\
\text { plebiti } \\
\text { S }\end{array}$} & \multicolumn{4}{|c|}{ Lokasi pemasangan } & \multicolumn{2}{|c|}{ Total } \\
\hline & & \multicolumn{2}{|c|}{$\begin{array}{l}\text { Area } \\
\text { punggung }\end{array}$} & \multicolumn{2}{|c|}{$\begin{array}{l}\text { Area } \\
\text { pleksi }\end{array}$} & \multirow[b]{2}{*}{$\mathbf{f}$} & \multirow[b]{2}{*}{$\%$} \\
\hline & & f & $\%$ & $\mathbf{F}$ & $\%$ & & \\
\hline 1 & $\begin{array}{l}\text { Tidak } \\
\text { terjadi }\end{array}$ & 84 & 52,5 & 54 & 33,75 & 138 & 86,25 \\
\hline 2 & terjadi & 5 & 3,12 & 17 & 10,63 & 22 & 13,75 \\
\hline Tota & & 89 & 55,62 & 71 & 44,38 & 160 & 100 \\
\hline
\end{tabular}

Berdasarkan tabel diatas, diketahui bahwa mayoritas tidak terjadi plebitis yaitu 138 orang $(86,25 \%)$ dengan lokasi pemasangan adalah area punggung yaitu 84 orang $(52,5 \%)$ dan area pleksi yaitu 54 orang $(33,75 \%)$, sedangkan

minoritas terjadi plebitis yaitu 22 orang $(13,75 \%)$ dengan area punggung yaitu 5 orang $(3,12 \%)$ dan area pleksi yaitu 17 orang $(10,63 \%)$.

Tabel 7. Distribusi frekuensi responden berdasarkan hubungan kejadian plebitis dengan lamanya infus terpasang

\begin{tabular}{lllllllll}
\hline No & $\begin{array}{l}\text { Kejadian } \\
\text { plebitis }\end{array}$ & \multicolumn{3}{l}{ Lama Terpasang } & \multicolumn{2}{l}{ Total } \\
\cline { 3 - 6 } & & \multicolumn{2}{c}{$<$ hari } & \multicolumn{2}{c}{$\mathbf{3}$ hari } & & \\
\cline { 2 - 6 } & & $\mathbf{f}$ & $\mathbf{\%}$ & $\mathbf{f}$ & $\mathbf{\%}$ & f & \% \\
\hline 1 & $\begin{array}{l}\text { Tidak } \\
\text { terjadi }\end{array}$ & 69 & 43,125 & 69 & 43,125 & 138 & 86,25 \\
\hline 2 & terjadi & 0 & 0 & 22 & 13,75 & 22 & 13,75 \\
\hline Total & & 69 & 43,125 & 91 & 56,875 & 160 & 100 \\
\hline
\end{tabular}

Berdasarkan tabel diatas, diketahui bahwa yaitu 22 orang $(13,75 \%)$ dengan lama mayoritas tidak terjadi plebitis yaitu 138 orang $(86,25 \%)$ dengan lama terpasang $<3$ hari yaitu 69 orang $(43,125 \%)$ dan $>3$ hari yaitu 69 orang $(43,125 \%)$, sedangkan minoritas terjadi plebitis terpasang $<3$ hari yaitu 0 orang $(0 \%)$ dan lama terpasang $>3$ hari yaitu 22 orang $(13,75 \%)$.

Tabel 7. Distribusi frekuensi responden berdasarkan hubungan kejadian plebitis dengan jumlah insersi

\begin{tabular}{llllllll}
\hline No & $\begin{array}{l}\text { Kejadi } \\
\text { an } \\
\end{array}$ & \multicolumn{2}{l}{\begin{tabular}{l}
\multicolumn{2}{l}{ Jumlah Insersi } \\
plebitis
\end{tabular}} & \multicolumn{1}{l}{$\mathbf{1}$ kali } & \multicolumn{3}{l}{ > 2 kali } \\
\cline { 3 - 8 } & & $\mathbf{f}$ & $\mathbf{\%}$ & $\mathbf{f}$ & $\mathbf{\%}$ & $\mathbf{f}$ & $\mathbf{\%}$ \\
\hline 1 & $\begin{array}{l}\text { Tidak } \\
\text { terjadi }\end{array}$ & 110 & 68,75 & 28 & 17,5 & 138 & 86,25 \\
\hline 2 & terjadi & 1 & 0,625 & 21 & 13,125 & 22 & 13,75 \\
\hline Total & & 111 & 69,375 & 49 & 30,625 & 160 & 100 \\
\hline
\end{tabular}

Berdasarkan tabel diatas, diketahui bahwa mayoritas tidak terjadi plebitis yaitu 138 orang $(86,25 \%)$ dengan insersi 1 kali insersi yaitu 110 orang $(68,75 \%)$ dan $>2$ kali insersi yaitu 28 orang $(17,5 \%)$, sedangkan minoritas terjadi plebitis yaitu 22 orang $(13,75 \%)$ dengan jumlah insersi 1 kali yaitu 1 orang $(0,625 \%)$ dan insersi > 2 kali yaitu 21 orang $(13,125 \%)$.

\section{PEMBAHASAN}

Hasil penelitian menunjukkan bahwa mayoritas ukuran infus yang digunakan adalah ukuran 22 yaitu 102 orang $(98,24 \%)$ dan minoritas menggunakan ukuran 20 yaitu 58 orang $(1,76 \%)$. Hasil analisis chi square diperoleh nilai $\mathrm{p}$ hitung $0,000<\mathrm{p}$ value artinya ada hubungan ukuran infus dengan plebitis. 
Ukuran infus berkisar antara 16-24 gauge yang dapat dibedakan dengan warna dan panjangnya 25-45 mm. Ukuran infus dipengaruhi oleh faktor- faktor sebagai berikut :durasi dan komposisi cairan infus, kondisi klinik, ukuran dan kondisi vena.

Dimana ukuran tersebut antara lain adalah 14 G(warna coklat), 16G (warna abu-abu), $17 \mathrm{G}$ (Warna putih), 18 gauge (warna hijau) digunakan pada pasien trauma, pembedahan dan transfusi darah. Ukuran 20G (warna merah muda) digunakan pada pasien infus kontinu atau intermitten dan transfusi darah, 22G (warna biru) digunakan pada pasien infus intermitten umum dan anak-anak dan pasien lansia) dan $24 \mathrm{G}$ (warna kuning) digunakan pada pasien vena fragil untuk infus intermiten atau kontinu (Wayunah, 2011).

Sesuai dengan teori menurut Stikowski (2009) yang menyatakan bahwa penyebab Flebitis yang terjadi secara mekanis (mechanical flebitis) terjadi ketika ada pergerakan benda asing (kateter intravena) dalam pembuluh darah yang menyebabkan gesekan dan peradangan vena. Pada penelitian ini kejadian flebitis yang terjadi karena ukuran katater intravena yang dipasang tidak sesuai dengan ukuran vena pasien sehingga mudah terjadi gesekan ketika pasien bergerak sehingga terjadi peradangan di sekitar area yang terpasang infus.

\section{Jenis Cairan}

Hasil penelitian mayoritas jenis cairan yang digunakan adalah ukuran hipotonik yaitu 94 orang $(58,8 \%)$ dan minoritas hipertonik yaitu 66 orang $(41,3 \%)$. Analisis data dengan menggunakan chi square diperoleh nilai $p$ hitung $(0,000)<p$ value $(0,05)$ artinya ada hubungan jenis cairan dengan kejadian plebitis. Cairan hipotonik: osmolaritasnya lebih rendah dibandingkan serum (konsentrasi ion $\mathrm{Na}+$ lebih rendah dibandingkan serum), sehingga larut dalam serum, dan menurunkan osmolaritas serum. Maka cairan "ditarik" dari dalam pembuluh darah keluar ke jaringan sekitarnya (prinsip cairan berpindah dari osmolaritas rendah ke osmolaritas tinggi), sampai akhirnya mengisi sel-sel yang dituju. Digunakan pada keadaan sel "mengalami" dehidrasi, misalnya pada pasien cuci darah, juga pada pasien hiperglikemia (kadar gula darah tinggi) dengan ketoasidosis diabetik.

Komplikasi yang membahayakan adalah perpindahan tiba-tiba cairan dari dalam pembuluh darah ke sel, menyebabkan kolaps kardiovaskular dan peningkatan tekanan intrakranial (dalam otak) pada beberapa orang ( $\mathrm{NaCl} /$ salin $0,45 \%$, salin 0,33\% dan Dekstrosa $2,5 \%)$. Cairan hipertonik: osmolaritasnya lebih tinggi dibandingkan serum, sehingga "menarik" cairan dan elektrolit dari jaringan dan sel ke dalam pembuluh darah. Mampu menstabilkan tekanan darah, meningkatkan produksi urin, dan mengurangi edema (bengkak). Penggunaa nnya kontradiktif dengan cairan Hipotonik. Misalnya Dextrose $5 \%$ + salin $0,45 \%$, salin $3 \%$, Dextrose 5\%+Ringer- Lactate, Dextrose $5 \%+\mathrm{NaCl} 0,9 \%$, produk darah (darah), dan albumin (Perry \& Potter, 2005).

Osmolalitas diartikan sebagai konsentrasi sebuah larutan atau jumlah partikel yang larut dalam suatu larutan. Pada orang sehat,konsentr asi plasma manusia adalah $285 \pm 10 \mathrm{mOsm} / \mathrm{kg}$ H20. Larutan sering dikategorikan sebagai larutan isotonik, hipotonik atau hipertonik, sesuai dengan osmolalitas total larutan tersebut dibanding dengan osmolalitas plasma. Larutan isotonik adalah larutan yang memiliki osmolalitas total sebesar $280-310 \mathrm{mOsm} / \mathrm{L}$, larutan yang memiliki osmolalitas kurang dari itu disebut hipotonik, sedangkan yang melebihi disebut larutan hipertonik. Tonisitas suatu larutan tidak hanya berpengaruh terhadap status fisik klien akan tetapi juga berpengaruh terhadap tunika intima pembuluh darah. Dinding tunika intima akan mengalami trauma pada pemberian larutan hiperosmoler yang mempunyai osmolalitas lebih dari 600 $\mathrm{mOsm} / \mathrm{L}$.

\section{Lokasi Pemasangan}

Hasil penelitian mayoritas lokasi pemasangan infus dilakukan di area punggung yaitu 89 orang $(55,6 \%)$ dan minoritas area fleksi yaitu 71 orang $(44,4 \%)$. Analisis statistik chi square menunjukkan nilai p hitung $0,001<$ $\mathrm{p}$ value $(0,05)$ artinya ada hubungan lokasi 
pemasangan dengan kejadian plebitis. Menurut La Rocca (2011) perkiraan lokasi pemasangan terapi infus menjadi faktor yang lebih penting dalam seleksi pembuluh. Pilihlah pembuluh darah yang panjang dan tidak bercabang. Untuk itu lokasi penusukan jarum infus mulai dari sejauh mungkin dan berpindah dalam arah proksiamal pada kedua tangn secara bergantian. Vena-vena yang digunkan untuk terapi intravena adaalah vena metacarpal atau area punggung tangan, vena sefalica dan basalica atau pergelangan tangan, hindari penggunaan pada daerah lipatan tangan dan siku, karena lipatan siku atau lengan mengakibatkan pelipatan kanula dalam pembuluh darah dan menimbulkan komplikasi terjadinya flebitis.

Berdasarkan hasil penelitian dan teori yang ada, penelitian menyimpulkan bahwa lokasi pemasangan infus berpengaruh terhadap kejadian flebitis. Hal ini terlihat dengan jelas pada hasil penelitian yang peneliti lakukan, pasien yang terpasangan infus dengan lokasi pemasangan di vena metacarpal sebagian besar mengalami flebitis. Seperti yang kita ketahui daerah metakarpal sangat gampang untuk berubah karena daerah ini adalah bahagian yang sangat mudah untuk bergerak dan sebagai ekstremitas untuk motorik. Vena basilaris (vena pergelangan tangan dan lengan) sering diabaikan karena posisinya yang tidak menarik perhatian yaitu pada perbatasan ulnaris dan lengan bawah.Kanulasi yang dilakukan dapat menjadi canggung karena posisinya tersebut, dan mobilitas serta kecenderungan memiliki banyak katup (Wayunah 2011).

\section{Lama Infus Terpasang}

Hasil penelitian mayoritas lamanya infus terpasang yaitu $>3$ hari yaitu 91 orang $(56,9 \%)$ dan minoritas lama infus terpasang $<3$ hari yaitu 69 orang $(43,1 \%)$. Analisis data statistik menunjukkan nilai $\mathrm{p}$ hitung $0,000<\mathrm{p}$ value $(0,05)$ artinya ada hubungan lama infus terpasang dengan kejadian plebitis. Hasil penelitian ini didukung oleh Lidya Devega (2009), di Ruang Rawat Inap Interne RSUD Dr. Ahcmad Mochtar Bukittinggi. Penelitian dilakukan pada 30 orang respnden yang mendapat cairan intravena. Lama pemasangan $\geq 72$ jam sebanyak 16 orang dan $<72$ jam sebanyak 14 orang. Dari 16 orang yang terpasang infus $\geq 72$ jam sebnyak 12 orang $(75 \%)$ terjadi flebitis.

Menurut Brunner and Suddart (2008), batas lama waktunya penggunaan kateter intravena tersebut hanya 48-72 jam. Jika hal tersebut dibiarkan maka akan mempermudah timbulnya peradangan pada pembuluh vena, karena adanya kolonisasi kuman atau bakteri pada daerah penusukan kanula atau pada kepala kanula itu sendiri. Untuk itu sebaiknya kateter intravena diganti tiap 72 jam, meskipun belum ada tanda-tanda flebitis maupun pembekuan kateter. Bila timbul tanda-tanda nyeri, kemerahan, pembengkakan dan rasa hangat pada daerah sekitar penusukan kanula intravena maka secepatnya kateter dilepas atau diganti. Menurut asumsi peneliti bahwa lama terpasang infus berpengaruh terhadap kejadian flebitis. Apabila pemasangan infus $\geq 72$ jam maka akan berpeluang untuk terjadinya flebitis. Hal ini disebabkan mudahnya masuk kuman pada area pemasangan infus karena daerah tusukan sudah meruapakan jendela bagi mikro organisme dari luar tubuh untuk masuk kedalam tubuh. Pernyataan ini didukung oleh Brunner and Suddart (2008), yang menyatakan bahwa batas lama waktunya penggunaan kateter intravena tersebut hanya 48-72 jam. Jika hal tersebut dibiarkan maka akan mempermudah timbulnya peradangan pada pembuluh vena, karena adanya kolonisasi kuman atau bakteri pada daerah penusukan kanula intravena.

Pada penelitian yang dilakukan oleh Komaling dkk (2014) diketahui bahwa dari total 21 responden yang lama pemasangan infus lebih dari 72 jam ( $\geq 3$ hari), 16 responden $(27,6 \%)$ mengalami phlebitis, sedangkan 5 responden $(8,6 \%)$ tidak mengalami phlebitis. Sedangkan dari 37 responden yang dipasangi infus $48-72$ jam ( $\leq 3$ hari), 4 responden $(6,9 \%)$ mengalami phlebitis, sedangkan 33 responden $(56,9 \%)$ tidak mengalami phlebitis (Komaling, 2014).

\section{Jumlah Insersi}

Hasil penelitian mayoritas jumlah insersi atau penusukan infus 1 kali penusukan yaitu 111 orang $(69,4 \%)$ dan minoritas $\geq 2$ kali penusukan yaitu 49 orang $(30,6 \%)$. Analisis 
statistik menunjukkan nilai $\mathrm{p}$ hitung $0,000<\mathrm{p}$ value $(0,05)$ artinya ada hubungan jumlah insersi dengan kejadian plebitis. Jumlah insersi yang dimaksud adalah jumlah insersi (penusukan) infus yang dilakukan oleh perawat sebelum insersi yang berhasil (Ignativicius et al, (2010) dalam Wayunah (2011). Insersi ini tidak boleh lebih dari 2 kali oleh seorang perawat. Berdasarkan hasil penelitian diketahui bahwa kejadian phlebitis pada pemasangan kateter intravena dengan tehnik insersi kurang baik sebanyak 49 responden $(30,6 \%)$ Hasil penelitian ini sesuai dengan hasil penelitian Pearson (2010) yang mengatakan bahwa insersi pada vena yang terpasang infus mempunyai resiko terjadi phlebitis. Phlebitis dapat terjadi akibat tidak adanya mekanisme untuk mempertahankan tehnik insersi pada pertama kali.

Kejadian phlebitis terjadi disebabkan karena tehnik insersi intravena yang tidak dilakukan dengan benar dapat menyebabkan perlukaan pada lokasi insersi yang dapat dijadikan sebagai port de entry bagi mikroorganisme. Adanya luka menyebabkan mikroorganisme berkembang dan menyebabkan adanya tanda-tanda phlebitis yang ditunjukkan dengan adanya bengkak pada daerah pemasangan, teraba nyeri, kemerahan dan teraba hangat (Perry \& Potter, 2009).Bengkak pada daerah pemasangan dan teraba nyeri yang terjadi muncul akibat aliran cairan infus tertahan pada daerah insersi yang kemungkinan disebabkan oleh karena perubahan posisi abocath dalam pembuluh darah vena. Sedangkan nyeri muncul akibat adanya bengkak pada daerah insersi infus. Kemerahan serta teraba hangat merupakan tanda peradangan lanjut setelah bengkak dan nyeri. Kemerahan serta teraba hangat merupakan indikasi telah terjadinya peradangan dalam waktu yang lama (Prajoko, 2009).

\section{KESIMPULAN}

1. Berdasarkan ukuran infus mayoritas digunakan adalah ukuran 22 yaitu 102 orang $(98,24 \%)$ dan minoritas ukuran 20 yaitu 58 orang $(1,76 \%)$. Nilai $p=0,000$ ada hubungan ukuran infus dengan phlebitis.
2. Berdasarkan jenis cairan yang digunakan adalah ukuran hipotonik yaitu 94 orang $(58,8 \%)$ dan minoritas hipertonik yaitu 66 orang $(41,3 \%)$. Nilai $p$ value 0,000 ada hubungan jenis cairan dengan phlebitis.

3. Berdasarkan lokasi pemasangan infus mayoritas dilakukan di area punggung yaitu 89 orang $(55,6 \%)$ dan minoritas area fleksi yaitu 71 orang $(44,4 \%)$. Nilai p 0,001 ada hubungan lokasi pemasangan dengan phlebitis.

4. Berdasarkan lama infus terpasang mayoritas yaitu > 3 hari yaitu 91 orang $(56,9 \%)$ dan minoritas lama infus terpasang $<3$ hari yaitu 69 orang $(43,1 \%)$. Nilai $p$ value 0,000 ada hubungan lama infus terpasang dengan plbitis.

5. Berdasarkan jumlah insersi mayoritas 1 kali penusukan yaitu 111 orang $(69,4 \%)$ dan minoritas $\geq 2$ kali penusukan yaitu 49 orang (30,6\%). Nilai $p$ value 0,000 ada hubungan jumlah insersi dengan plebitis.

\section{SARAN}

1. Penelitian ini hendaknya berguna untuk peneliti selanjutnya, dan disarankan menjadi referensi penelitian yang sama dengan jumlah sampel yang lebih besar dan di tempat yang berbeda.

2. Disarankan kepada responden agar tetap meningkatkan kinerja secara profesional untuk mencegah terjadinya phlebitis.

3. Agar mengevaluasi kembali tentang faktor penyebab terjadinya plebitis sehingga angka kejadian plebitis bisa berkurang atau tidak terjadi sama sekali, diantaranya tentang keterampilan perawat dalam melakukan pemberian infus.

\section{DAFTAR PUSTAKA}

Alexander, M, et al. (2011). Infusion Nursing Society, Infusion Nursing, An EvidenceBassed Aproach. St.Louis: Dauger Elvier.

Brunner \& Suddart. (2008). Keperawatan Medical Bedah. Jakarta: EGC.

Darmadi. (2008). Infeksi Nosokomial: Problem atika Dan Pengendaliannya. Jakarta: Salemba Medika. 
Darmawan, I. (2008). Phlebitis, Apa Penyebab nya Dan Bagaimana Cara Mengatasinya. http://www.otsuka.co.id/?content=article detail\&id=68\&lag=id. Diperoleh tanggal 26 Maret 2018

Depkes RI. (2013). Pedoman Pelaksanaan Kewaspadaan Universal di Pelayanan Kesehatan. Jakarta: Departemen Kesehata n RI.

Hidayat. (2008). Pengantar Kebutuhan Dasar Manusia : Aplikasi Konsep dan Proses Keperawatan. Jakarta: Salemba Medika.

Hinlay. (2006). Terapi Intravena pada Pasien di Rumah Sakit. Yogyakarta: Nuha Medika.

INS. (2010). Setting the Standard for Infusion Care. Diambil tanggal 2 April 2018 diakses melalui http://www.ins1.org.

Komaling, C. (2014). Hubungan Lamanya Pemasangan Infus (Intravena) Dengan
Kejadian Flebitis Pada Pasiendi Irina F Blu Rsup Prof. Dr. R. D. Kandou manado.

Lukman. (2007). Intravena Terapi. http://www.sehatgrup.com. Di akses pada tanggal 23 Maret 2018.

Nihi, S. 2011. Gambaran Penderita Infeksi Nosokomial Pada Pasien Rawat Inap Di Rsup Dr. Wahidin Sudurohusodo Tahun 2010. (Skripsi). Makassar: Fakultas Kedokteran Universitas Hassanudin.

Perry dan Potter, (2009). Buku Ajar Fundamental Keperawatan Konsep, Proses dan Praktek. Edisi 4. Alih bahasa Renata Komalasari. Jakarta: EGC.

Septiari, B. (2012). Infeksi Nosokomial. Jakarta: Nuha Medika.

Wayunah . (2011). Hubungan Pengetahuan Perawat Tentang Terapi Infus Dengan Kejadian Plebitis Dan Kenyamanan Pasien Di Ruang Rawat Inap Rsud Indramayu. skripsi: Tidak dipublikasikan.

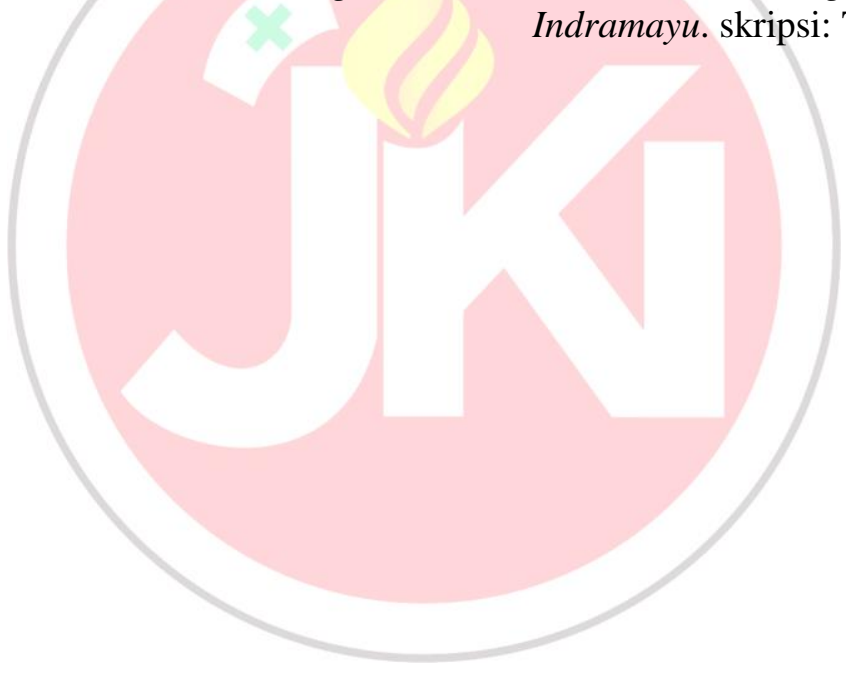

